\title{
A Rare Case of Gastric Linitis Plastica Revealed by Isolated Vertebral Metastases in a Young Woman in a Less Developed Country
}

\author{
Zavier Zomalheto, Raimi Kpossou, Anthelme Agbodande, Jean-Paul Larbre \\ Rheumatology Hospital Unit of National Hospital University, Cotonou, Benin \\ Email: zozaher@yahoo.fr, k raimi@hotmail.com, agbotem@yahoo.fr, cosherv12@yahoo.fr
}

Received 10 August 2014; revised 10 September 2014; accepted 10 October 2014

Copyright (C 2014 by authors and Scientific Research Publishing Inc.

This work is licensed under the Creative Commons Attribution International License (CC BY). http://creativecommons.org/licenses/by/4.0/

(c) (i) Open Access

\begin{abstract}
Aim: We report a rare case of gastric linitis plastica revealed by vertebral metastases without another digestive dissemination. Case presentation: The Benin native woman was hospitalized in rheumatology for inflammatory back pain without another signs. Rx ray showed vertebra metastasis. In the etiologic research, gastroscopy showed an infiltrating lesion of the antral area, indicating gastric linitis which was confirmed by biopsy. Short and medium-term evolution was favourable, characterized by a complete disappearance of the pains and a good physical condition. Conclusion: Vertebral metastases can reveal digestive cancer, although human gut is not among the most bone metastatic cancers.
\end{abstract}

\section{Keywords}

Vertebral Metastasis, Gastric Linitis Plastica, Metastasis, Gastric Cancer

\section{Introduction}

Bone metastases are a frequent cause of hospital admissions in rheumatology. Its etiologic diagnosis raises a grave, difficult and frequent problem in rheumatologic practice. It is based on radiological appearance of the metastases, anamnesis, clinical examination, common biological investigation, imaging test, serum markers analysis and pathological anatomy [1]. It is inaugural in most cases of the metastatic cancers (up to $75 \%$ in the set of Vandecandelaere et al.) [2], making the primary site identification more difficult. However, thanks to the progress made in recent years especially in percutaneous bone biopsies using anatomopathological and immu- 
nomarking techniques, the primary site identification becomes less difficult [3]. About the young woman under the age of 40 , the so-called foul primary site is mainly breast cancer. The other cancers in particular stomach cancer are found in the older age group [4].

We however report a case of gastric linitis revealed by bone metastases in a 36-year-old woman.

\section{Observation}

The Benin native woman, born in 1974, with obesity history treated by gastric ring surgery in June 2004, was hospitalized in rheumatology for inflammatory back pain radiating in the bilateral intercostal area, and sternal pains, being quickly intensive since a month before her admission and becoming very disabling; these pains were not controlled with common antalgic drugs but responded to the morphine given by her treating physician. It was associated with an important asthenia. There were no anorexia neither weight loss and visceral clinical signs.

Clinical examination showed: well-being, pain caused by pressure on dorsal vertebral apophyses (T3-T11); visceral examination was normal.

Biologically, C-reactive protein rate was about $7 \mathrm{mg} / \mathrm{L}$ and erythrocyte sedimentation rate (ESR) $34 \mathrm{~mm}$ on the $1^{\text {st }}$ hour. There were no more biological disorders.

About the imaging tests, back-thoracic x-ray was normal (Figure 1); Spinal CT revealed osteolysis of the T8 vertebra, sternum and pelvis (Figure 2). A bone scan showed hyperfixation of the above-mentioned areas (Figure 3).

In the etiologic research, Thoraco-abdominal-pelvic CT confirmed bone injuries, the thyroid echography was normal; breast echography combined with mammography and breast MRI were not contributing. Myelogram was normal. Serum tumor markers showed only a discreet elevation of the CA 19-9. An anatomopathological study realized on biopsy samples taken from the left pubic symphysis identified "signet-ring cells" of adenocarcinoma indicating a gastric source. According to this result, gastroscopy showed an infiltrating lesion of the antral area, indicating gastric linitis which was confirmed by biopsy.

The diagnosis of primary gastric linitis with bone metastases was retained.

After a multidisciplinary discussion and account of the young age of the patient, an EOX chemotherapy (Epirubicin: $50 \mathrm{mg} / \mathrm{m}^{2} \mathrm{IV} 1^{\text {st }}$ day every 3 weeks, Oxaliplatin: $130 \mathrm{mg} / \mathrm{m}^{2} \mathrm{IV}$ over 2 hours $1^{\text {st }}$ day every 3 weeks, Capecitabine: $625 \mathrm{mg} / \mathrm{m}^{2}$ twice a day morning and evening, daily during all the chemotherapy length) and a cementoplasty of the $\mathrm{T} 8$ vertebra were decided.

Short and medium-term evolution was favourable, characterized by a complete disappearance of the pains and a good physical condition. The patient actually is still given the chemotherapy.

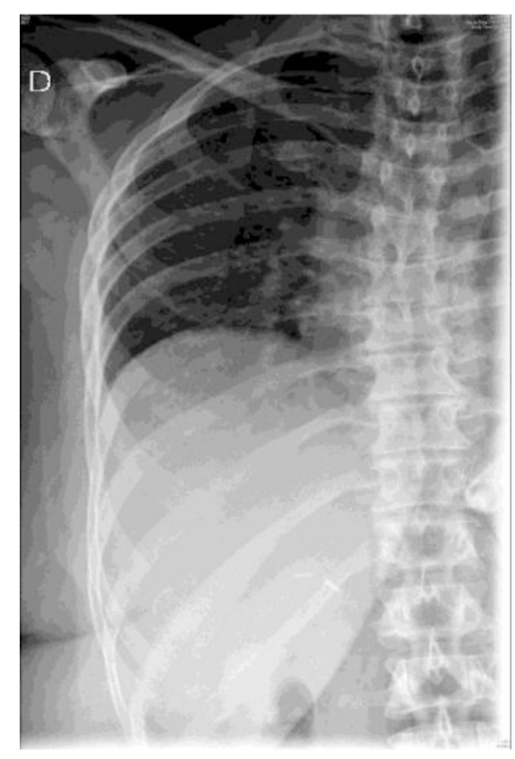

Figure 1. X ray of the thoracic spine. 


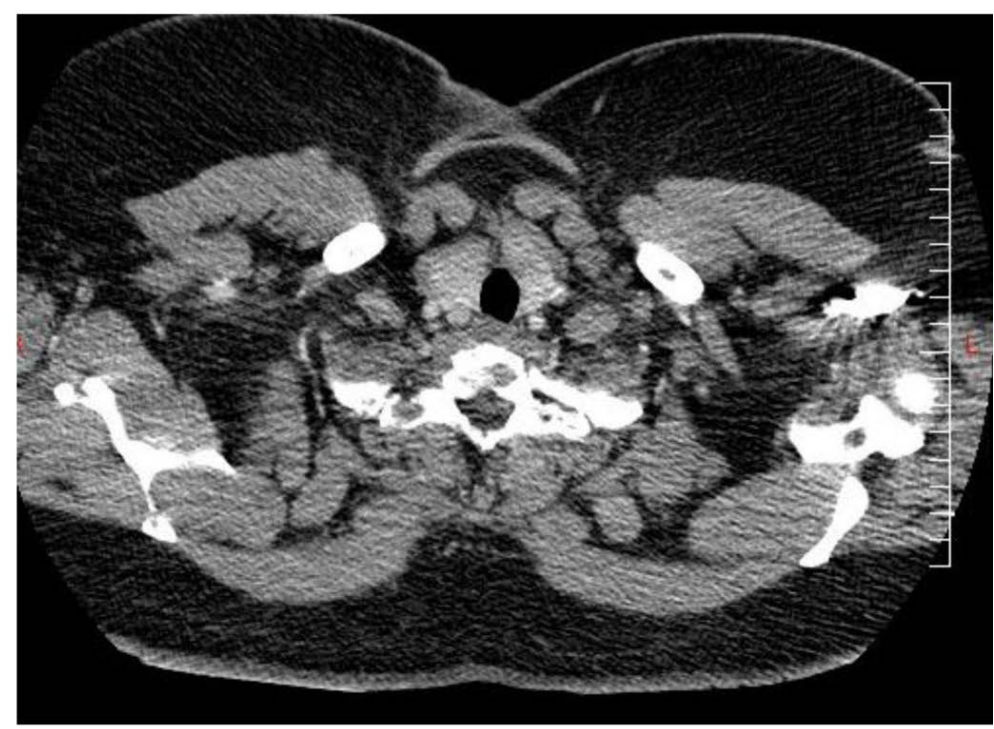

Figure 2. Spinal CT showing T8 osteolysis.

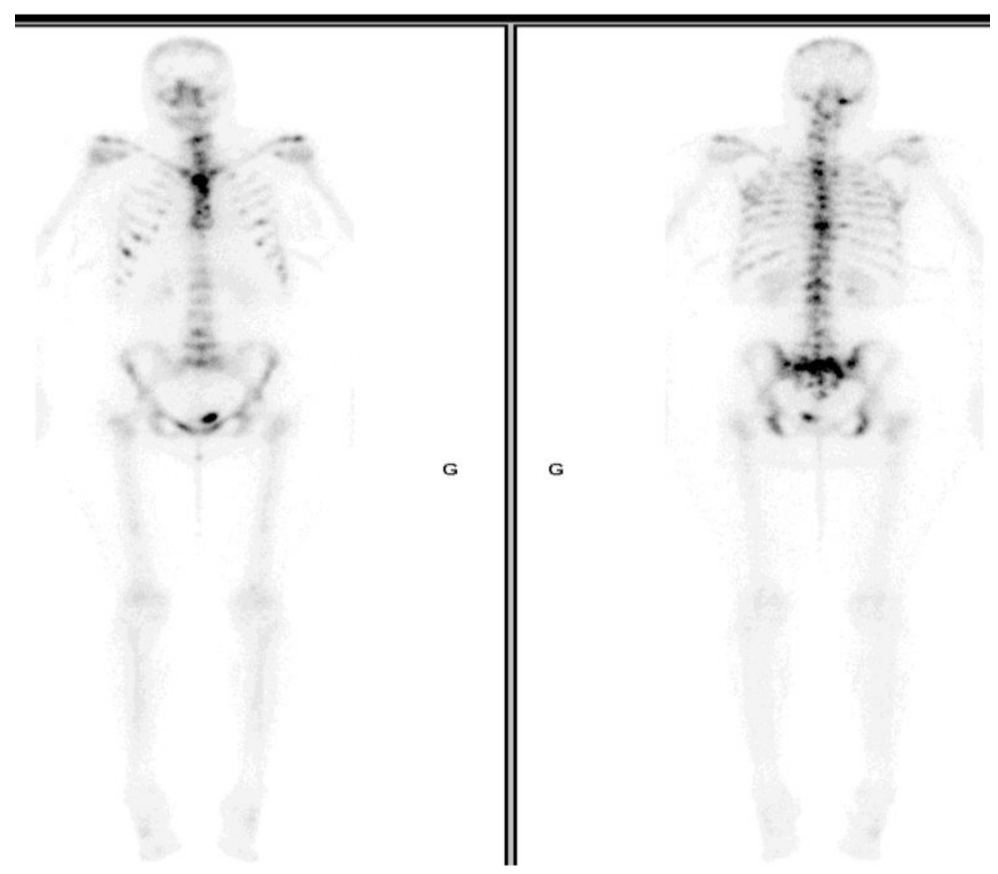

Figure 3. Bone scan: increased uptake of T8 sternum and pelvis.

\section{Discussion}

Gastric linitis plastica is a specific form of gastric cancer. It accounts 3\% - 19\% of the gastric cancers. In the set of Zagame et al. [5], most of cases are under the age of 60. Although gastric linitis also occurs at young people, any described case under 36 wasn't found as our case.

The disease preferentially affects women and starts in the cardia area [6]. It is not preceded by chronic atrophic gastritis and it projects from a healthy mucous membrane. Its etiopathogeny is not known and differs from the one of gastric adenocarcinomas [7]-[9]. Clinically, there is not any specificity for the clinician [10] [11]. Our patient didn’t present any gastric sign.

The low sensitivity of the endoscopy is due to biopsies difficulty. In the linitis, the clamp slides on the infiltrated walls. Radiological images are infiltration and rigidity: appearance of "leather bottle stomach', Echoen- 
doscopy is actually the most advanced examination which leads to define the concept of localized linitis. The diagnosis is based on morphological imaging showing entire stomach invaded with an infiltrating tumor. It is the $4^{\text {th }}$ histologic type of the WHO pathological records almost always with presence of signet ring cells in a fibrous stroma [12]. Its pattern of spread differs from the others gastric cancers in the high frequency of peritoneal and lymphatic impairment. Linitis quickly spreads in the peritoneal cavity. Metastases are rare and localized on rectum and colon walls [13]. We didn't found any described case of bone metastases in the literature such as in our case; nevertheless cutaneous metastases have been described [14].

Thoraco-abdominal-pelvic CT realized in our patient's case showed no digestive and peritoneal metastases. Bone injury could be due to the cancer cells hematogenous spread; however absence of loco-regional metastases explaining was not easy to us and was one of the particularity in our case.

Curative treatment is still radical surgical resection.

Although promising advances of modern treatment protocols by cancer agents derived from 5-FU (TS-1) and Paclitaxel are made, gastric linitis does not have a good response to the chemotherapy [5]-[10]. Our patient is given only chemotherapy account of the lesions spread in bones.

\section{Conclusion}

Gastric linitis very quickly spreads in the peritoneal cavity with a very bad prognosis. Extra-abdominal metastases are rarely described in the literature. The originality of this study comes from being the first report of linitis revealed by bones metastases in the literature and the very young age of our patient who didn't have any particular gastric history.

\section{References}

[1] Alcalay, M., Azais, I., Brigeon, B., Babin, P., Vandermarcq, P., Debiais, F. and Bontoux, D. (1995) Strategy for Identifying Primary Malignancies with Inaugural Bone Metastases. Revue du Rhumatisme (English ed.), 62, 632-642

[2] Vandecandelaere, M., Flipo, R.M., Cortet, B., Catanzariti, L., Duquesnoy, B. and Delcambre, B. (2004) Bone Metastases Revealing Primary Tumors. Comparison of Two Series Separated by 30 Years. Joint Bone Spine, 71, $224-229$. http://dx.doi.org/10.1016/S1297-319X(03)00123-4

[3] Karila-Cohen, P., Petit, T., Hotobi, H. and Merran, S. (2004) Gastric Leiomyosarcoma. Journal of Radiology, 85, 1993-1997. http://dx.doi.org/10.1016/S0221-0363(04)97771-2

[4] Destombes, C., Botton, E., Le Gal, G., et al. (2007) Investigations for Bone Metastasis from an Unknown Primary. Joint Bone Spine, 74, 85-89. http://dx.doi.org/10.1016/j.jbspin.2006.05.009

[5] Zagame, L., Boige, V., Malka, D., Fallik, D., Pocard, M., Villing, A.L., et al. (2004) Gastric Linitis Metastases: Descriptive and Prognostic Study. Clinical and Biological Gastroenterology. 1st Edition, Masson, Paris, A199.

[6] Walker, M.J. (1996) A Review of Carcinoma of the Stomach at a Tertiary Care Referral Hospital. The American Journal of Surgery, 172, 75-78. http://dx.doi.org/10.1016/S0002-9610(97)89550-5

[7] Yokoyama, T., Nakamura, H., Otani, Y., Kubota, T. and Fujimoto, N. (2004) Differences between Scirrhous and NonScirrhous Human Gastric Carcinoma from the Aspect of proMMP-2 Activation Regulated by TIMP-3. Clinical \& Experimental Metastasis, 21, 223-233. http://dx.doi.org/10.1023/B:CLIN.0000037704.72028.72

[8] Kazunori, N., Masakazu, Y. and Kosei, H. (2003) Keratinocyte Growth Factor Produced by Gastric Fibroblasts Specifically Stimulates Proliferation of Cancer Cells from Scirrhous Gastric Carcinoma. Cancer Research, 63, 8848-8852.

[9] Dussaulx-Garin, L., Blayau, M. and Pagenault, M. (2001) A New Mutation of E-Cadherin Gene in Familial Gastric Linitis Plastica Cancer with Extra-Digestive Dissemination. European Journal of Gastroenterology \& Hepatology, 13, 711-775. http://dx.doi.org/10.1097/00042737-200106000-00016

[10] Mohamed, I., Beyrouti, A., Ramez, B., Ben Amara, M., Frikhaa, F., et al. (2007) Gastric Linitis. La Presse Médicale, 36, 1782-1786.

[11] Ducreux, M., Boige, V. and Taieb, J. (2000) La linite: Une forme particulière de cancer gastrique. Mini-Revue, Hepato Gastro, 4, 263-267.

[12] Ventura, L., Chiominto, A., Discepoli, S., Ventura, T., Di Giacomo, C. and Leocata, P. (2002) Lack of Prognostic Significance in Goseki Grading of Gastric Carcinoma. Journal of Experimental Clinical Cancer Research, 21, 225-227.

[13] Jang, H.J, Lim, H.K., Kim, H.S., Cho, E.Y., Lee, S.J., Kim, K.A. et al. (2001) Intestinal Metastases from Gastric Adenocarcinoma: Helical CT Findings. Journal of Computer Assisted Tomography, 25, 61-67. http://dx.doi.org/10.1097/00004728-200101000-00011 
[14] Descamps, V., Makhlouf, R., Katchourine, I., Grossin, M. and Belaïch, S. (1995) Linitis Plastica Disclosed by Cervical Cutaneous Metastasis. Annales de Dermatologie et de Vénéréologie, 122, 108-110. 
Scientific Research Publishing (SCIRP) is one of the largest Open Access journal publishers. It is currently publishing more than 200 open access, online, peer-reviewed journals covering a wide range of academic disciplines. SCIRP serves the worldwide academic communities and contributes to the progress and application of science with its publication.

Other selected journals from SCIRP are listed as below. Submit your manuscript to us via either submit@scirp.org or Online Submission Portal.
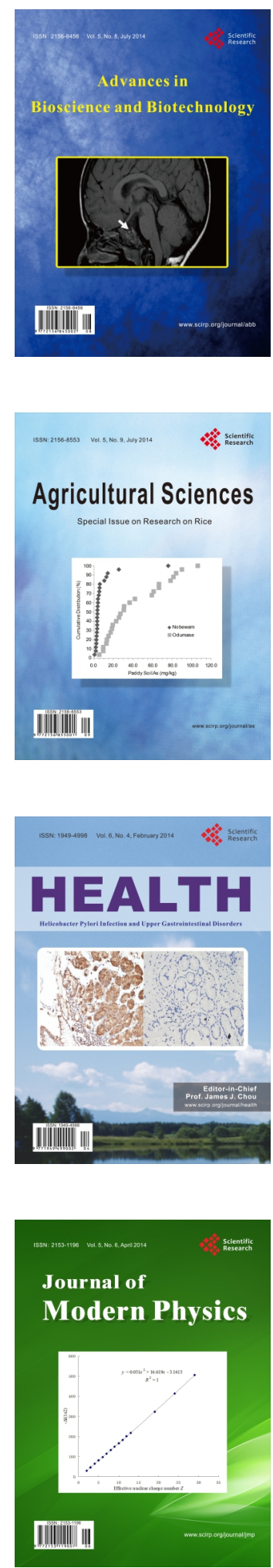
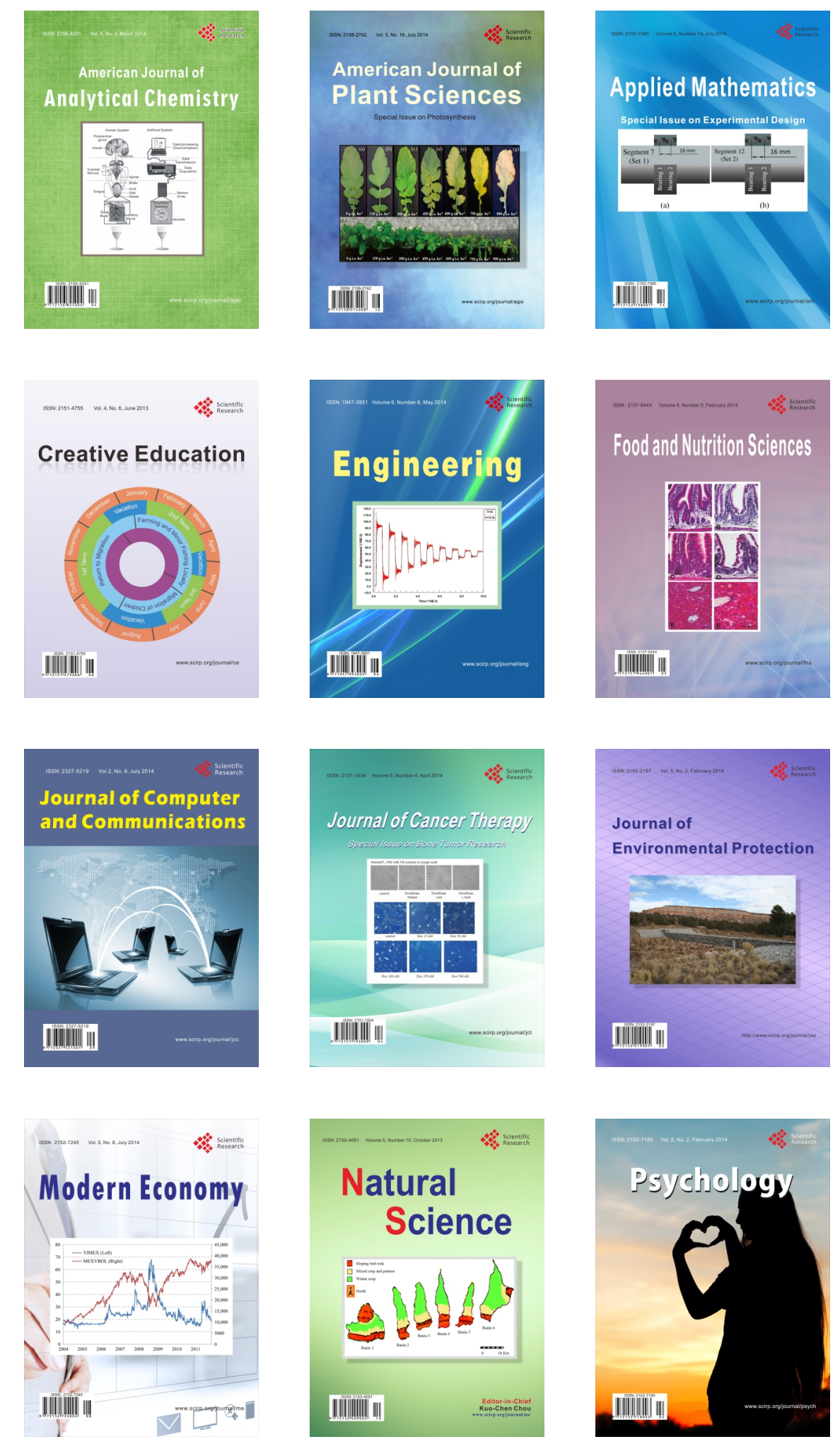